\title{
ПРИКЛАДНІ АСПЕКТИ МЕДСЕСТРИНСЬКОГО ПРОЦЕСУ У ВІДДІЛЕННІ ЗАГОТІВЛІ ДОНОРСЬКОЇ КРОВІ ТА ВИГОТОВЛЕННЯ ЇЇ КОМПОНЕНТІВ
}

\author{
Н. Ю. Лучишин ${ }^{1}$, Я. В. Гончаренко ${ }^{2}$ \\ ${ }^{1}$ Тернопільський національний медичний університет \\ імені І. Я. Горбачевського МОЗ Украӥни \\ ${ }^{2}$ НДСЛ «Охмадит», Центр служби крові, м. Київ
}

\begin{abstract}
У статті проаналізовано зміст медсестринського процесу в роботі медичної сестри відділення заготівлі донорської крові та виготовлення її компонентів. Зауважено, що робота цього відділення повинна бути доповнена правильно організованою діяльністю медичних сестер на всіх етапах: відбору і підготовки донора, заготівлі крові та їі компонентів, спостереження за донором у процесі донації та встановлення сестринського діагнозу у випадку виникнення реакцій.
\end{abstract}

\section{APPLIED ASPECTS OF THE NURSING PROCESS IN THE DEPARTMENT OF DONOR BLOOD PROCUREMENT AND BLOOD COMPONENT PRODUCTION}

\author{
N. Yu. Luchyshyn", Ya. V. Honcharenko² \\ ${ }^{1}$ I. Horbachevsky Ternopil National Medical University \\ ${ }^{2}$ National Children's Specialized Hospital “Okhmadyt”, Blood Service Center, Kyiv
}

\begin{abstract}
The article summarises the content of the nursing process in the Division of Blood and Blood Products. It is stated that the appropriate function of this division should be supported by properly organized work of nurses during all stages: donor selection and preparation, blood banking for the production of components, clinical observations of donors during donation, and establishing nursing diagnoses in case of adverse reactions.
\end{abstract}

Вступ. Служба крові - одна із галузей системи охорони здоров'я, стратегічним напрямком якої $\epsilon$ стабільне, безперебійне забезпечення лікувальних закладів якісними та безпечними гемотрансфузійними середовищами. Заклади служби крові, відділення трансфузіології, трансфузіологічні кабінети, лікувально-профілактичні заклади організовують залучення населення до донорства крові та її компонентів, проводять заготівлю свіжозамороженої плазми та клітинних компонентів донорської крові [1]. Протягом останніх років у світі спостерігають дві різнонаправлені тенденції: зростання потреби у препаратах крові та зменшення кількості донорів крові та ії компонентів [2]. Попри розробку розпоряджень, згідно з якими щорічно затверджують обсяги обов'язкового забезпечення потреб охорони здоров'я населення донорською кров'ю, її компонентами і препаратами, з кожним роком в Україні стає все більш актуальною проблема зростання обмежень на шляху () Н. Ю. Лучишин, Я. В. Гончаренко, 2021 потенційного донора та поширення захворювань серед населення.

Процедури забору, обробки та зберігання крові зараз є складними, стандартизованими процесами, регламентованими Законом України «Про безпеку та якість донорської крові та компонентів крові» [1]. Відповідно до Закону, персонал, безпосередньо задіяний у взятті, тестуванні, переробці, зберіганні та розподілі донорської крові, її компонентів та препаратів, повинен мати кваліфікацію, відповідну для виконання цих завдань, вчасно проходити відповідне навчання та постійно підвищувати кваліфікацію. Отже, на сестринський персонал покладається широкий спектр обов'язків, що вимагає від медичних сестер застосування належних підходів до забору і обробки крові, розуміння принципів гемопильності, знання причин виникнення ускладнень і факторів, що впливають на здоров'я донорів. Недостатня підготовленість середнього медичного персоналу в теорії і практиці заготівлі крові, неуважність у роботі з донорами, недостатній 
ступінь організації і ресурсного забезпечення можуть стати причинами небажаних ускладнень. Це робить актуальним питання відповідної підготовки медичних сестер відділень заготівлі крові.

Основна частина. Сфера діяльності медичної сестри відділення заготівлі донорської крові та виготовлення ії компонентів жорстко регламентована існуючими стандартами, згідно з якими процес заготівлі донорської крові проводять у межах зони, призначеної для безпечного виконання цієї процедури у донорів та, відповідно, обладнаної для надання першої медичної допомоги донорам при виникненні негативних реакцій або ускладнень при виконанні функцій, пов'язаних із донорством крові [3]. Попри виконання загальних і спеціальних обов'язків, головним пріоритетом медичної сестри, яка відповідає за проведення забору донорської крові, є догляд за донором та безпека крові. Вона приймає важливі медичні рішення щодо придатності донора до донації, що вимагає відповідних медичних знань та підготовки. 3 огляду на це, під час роботи у відділенні заготівлі донорської крові та виготовлення її компонентів медична сестра повинна бути обізнана з особливостями здійснення сестринського процесу з метою забезпечення безпечної та якісної донації крові [4-7].

Особливостями першого етапу медсестринського процесу при роботі у відділенні заготівлі донорської крові та виготовлення їі компонентів $є$ ідентифікація донора - перевірка паспортних даних та направлення донора на здачу крові. Медичній сестрі необхідно знати, що за законом донором крові та ії компонентів може бути будь-який дієздатний громадянин України, іноземець чи особа без громадянства, яка має посвідку на постійне проживання на території України, яка не має протипоказань, визначених Міністерством охорони здоров'я України. При цьому існує перелік захворювань, хворіючи на які людина ніколи не може здавати кров: це вірусні гепатити В і С, ВІЛ, сифіліс, туберкульоз, бруцельоз, туляремія, а також паразитарні, злоякісні хвороби, хронічні захворювання серцево-судинної, дихальної та сечовидільної систем, шлунково-кишкового тракту, операції з видалення будь-якого органа тощо. Донором ніколи не зможе стати людина, хвора на псоріаз, екзему, гіпертонічну хворобу II-ІІІ ступенів, ішемічну хворобу серця, бронхіальну астму, у якої була злоякісна пухлина (навіть після успішного лікування), пацієнт із променевою хворобою, цирозом печінки, значним ураженням нирок, виразковою хворобою шлунка чи дванадця- типалої кишки, міопією тяжкого ступеня. Крім того, $€$ список тимчасових станів, що перешкоджають донорству: будь-які операції, в тому числі аборти, нанесення татуювання або лікування голковколюванням, перебування за кордоном більше двох місяців, контакт із хворим на гепатит A, B або C, перенесена ангіна, грип, застуда, інші інфекційні захворювання, алергічні захворювання у стадії загострення, щеплення, приймання антибіотиків, менструація, видалення зуба, вживання алкоголю [8]. У центрі уваги такого відбору донорів $є$ безпека як його, так і реципієнта.

Деколи, коли виникає ситуація відмови донору, йому буде важко це сприйняти. Роль медичної сестри у такому випадку - бути чутливою до потреб донора та забезпечити мотивацію прийти пізніше, при можливості [4]. Якщо волонтер не може повернутися, важливо, щоб медсестра чітко повідомила причину рішення та висловила вдячність за зусилля, які людина доклала, щоб допомогти іншим. У зв'язку із регулярними змінами, що вносять до керівних принципів відбору донорів, медичні сестри змушені виконувати актуальні вказівки та гарантувати, що нові та основні підходи застосовують на практиці.

Медичній сестрі потрібно знати, що напередодні донації донор повинен утриматися від споживання жирних, смажених і молочних страв, вживання алкоголю за 48 год до здачі крові, а також від приймання аспірину, анальгіну і ліків, що їх містять (за 72 год) до процедури, по можливості утриматися від куріння (за 1 год) та добре виспатися.

Медична сестра здійснює медичний огляд донора, готує його до взяття крові, здійснює маркування контейнерів, флаконів, пробірок, правильно обробляє ліктьовий згин донора і накладає джгут. При цьому вона дотримується вимог асептики і антисептики, здійснює відповідну обробку рук і одягає стерильний медичний халат, стерильні гумові рукавички.

Донорську кров заготовляють в стерильні закриті системи; антисептик і місце венозного доступу обирають та підготовлюють таким чином, щоб мінімізувати ризик бактеріальної та вірусної контамінації. На етикетках готової продукції зазначають ідентифікаційний номер донора та його штрих-код, який $\epsilon$ унікальним для кожного донора в закладі служби крові. Враховуючи те, що на контейнерах із компонентами крові, які видають в лікувальну мережу, прізвище донора не вказують, саме його ідентифікатор забезпечує можливість швидкого пошуку всієї необхідної інформації про даного донора. 
Система тестування донорської крові відіграє дуже важливу роль у забезпеченні безпечного постачання кров'ю та її препаратами пацієнтів-реципієнтів. Медична сестра проводить серологічне, імуногематологічне та біохімічне дослідження крові донора на інфекції, які можуть передаватися від донора пацієнту при гемотрансфузії (обов'язкові вірусологічні тести на визначення маркерів збудників трансфузійно-трансмісивних інфекцій: ВІЛ-1/2, гепатитів С і В, сифілісу). Додаткові тести проводять на вибраних зразках або на основі інформації, наданої донором, або для задоволення потреб певних пацієнтів. Спектр аналізів крові, що проводить центр крові, регулярно переглядають $[1,4,8]$.

Під час донації крові медична сестра відстежує динаміку стану донора, а також якість процедури забору крові. Об'єм крові в контейнері повинен знаходитися в межах, встановлених нормативною документацією на конкретний тип контейнера, і відразу ж після заповнення пробірки зразки крові ідентифікують та маркують. Тривалість донації крові не повинна перевищувати 10 хв, а в разі перевищення названої межі в обов'язки медичної сестри входить реєстрація цього відхилення. Кров, заготовлена з порушенням встановлених вимог (більше одного проколу вени, неповна доза крові), для трансфузії в подальшому не використовують. До інших відхилень упроцесі донації крові належать реакції донорів. Якщо медична сестра несвоєчасно розпізнає проблеми донора, не складе і не реалізує план догляду за ним, то це призведе до розвитку ускладнень. До тяжких реакцій належать непритомність, що призвела до травми, розвиток серцево-судинної недостатності, ушкодження нерва, артерії або інфікування в місці проколу. Усі реакції, як тяжкі, так і легкі, ступінь їх тяжкості медична сестра реєструє у картці донора $[9,10]$. У разі потреби вона надає невідкладну домедичну допомогу відповідно до стандартної операційної процедури: за відсутності дихання повідомляє лікаря та проводить серцеволегеневу реанімацію; при наявності дихання та за відсутності травм переводить донора у стабільне положення, контролює дихання.

Не менш важливим аспектом сестринського процесу $є$ створення зони для безпечної утилізації відходів, одноразового витратного матеріалу, що використовують під час взяття, тестування та переробки крові, а також для забракованої крові та ії компонентів. Утилізація відбувається відповідно до діючих санітарно-епідеміологічних норм. Варто наголосити, що кожен випадок утилізації компонентів донорської крові повинен бути чітко задокументованим.

Висновки. Незважаючи на мінімальний контакт із людиною-донором, медична сестра повинна сумлінно виконувати свої обов'язки: бути вимогливою щодо виконання правил асептики і антисептики, дисципліни, встановлювати доброзичливі, етично коректні взаємини з донором. Використання в роботі стандартів допомагає сестринському персоналу деталізувати дії при виконанні процедури заготівлі крові та виготовленні її компонентів, більш ефективно організувати роботу з донорами. Процес заготівлі донорської крові та її компонентів вимагає створення стерильних умов на всіх етапах - від обробки апаратури до процедури взяття крові від донора. Ці вимоги можна виконати тільки при наявності добре підготовленого і відповідального медперсоналу: лікаря-хірурга, медичної сестри і операційної медичної сестри відділення заготівлі крові. Використання досягнень сестринського процесу повинно бути повсякденним і постійним, що дасть змогу медичній сестрі оволодіти спеціальними знаннями, навичками, уміннями, з можливістю їх правильного практичного застосування, та сприятиме розвитку прихильності донорів і їх готовності до добровільного донорства крові.

\section{СПИСОК ЛІТЕРАТУРИ}

1. Про безпеку та якість донорської крові та компонентів крові : Закон України від 30.09.2020 р. № 931-ІХ [Електронний ресурс]. - Режим доступу : https://zakon. rada.gov.ua/laws/show/931-20\#Text.

2. Безопасность крови и ее наличие в мире [Электронный ресурс] // Информационный бюллетень ВОЗ. Режим доступа : http://www.who.int/mediacentre/ factsheets/fs279/ru/.

3. Про затвердження Положення для установи переливання крові (щодо організації управління системою якості і безпеки донорської крові та ії компонентів) : наказ Міністерства охорони здоров'я України від 14.12.2010 р. № 1112.

4. Potok D. The role of nurses in blood services and donor sessions / D. Potok, D. Chandler // Nursing Times. - 2005. Vol. 101 (23). - P. 24-25. 
5. International blood collection and storage: Clinical use of blood products / W. Greening David, M. Glenister Kristen, L. Sparrow Rosemary, J. Simpson Richard // Journal of Proteomics. - 2009. - Vol. 73 (3). - P. 386-395.

6. Nursing care provided to blood donors from the perspective of integral healthcare / Nereida Lucia Palko dos Santos, Marluci Andrade Conceição Stipp, Ana Lúcia Abrahão da Silva [et al.] // Escola Anna Nery. - 2013.Vol. 17 (4). - P. 661-667.

7. Gonçalves H. Globalization and blood donors. How to improve the blood donation in the European Union (EU) / H. Gonçalves // ISBT Sci. Ser. - 2011. - Vol. 6, № 1. P. 142-147.
8. Організація трансфузіологічної служби у лікувальних закладах України [Електронний ресурс]. - Режим доступу: http://transfusiology.com.ua/wp-content/uploads/2019/01/ Rozdl-1-.pdf].

9. Heal Sarah Blood and Transplant Blood donation: nurse roles and responsibilities British / Sarah Heal, Claire Webster, Andrea Harris // Journal of Nursing. - 2019. - Vol. 28 (20). P. 1332-1334.

10. Теоретичні і практичні основи процесу сестринського догляду за пацієнтами : навч. посіб. / [Р. О. Сабадишин, О. В. Маркович, Б. З. Чижишин та ін.]. - Вінниця : Нова Книга, 2020. - 240 с.

Отримано 24.02.21 